\title{
Preferential Association of Interferon Regulatory Factor 5 Gene Variants with Seronegative Rheumatoid Arthritis in 2 Swedish Case-Control Studies
}

\author{
CHUAN WANG, HEIDI KOKKONEN, JOHANNA K. SANDLING, MARTIN JOHANSSON, MARIA SEDDIGHZADEH, \\ LEONID PADYUKOV, SOLBRITT RANTAPÄÄ-DAHLQVIST, and ANN-CHRISTINE SYVÄNEN
}

\begin{abstract}
Objective. Two interferon regulatory factor 5 (IRF5) gene variants were examined for association with rheumatoid arthritis (RA).

Methods. A total of 2300 patients with RA and 1836 controls were recruited from 2 independent RA studies in Sweden. One insertion-deletion polymorphism (CGGGG indel) and one single-nucleotide polymorphism (rs10488631) in the IRF5 gene were genotyped and analyzed within RA subgroups stratified by rheumatoid factor (RF) and anticitrullinated peptide antibodies (ACPA).

Results. The CGGGG indel was preferentially associated with the RF-negative (OR 1.29, $\mathrm{p}=7.9 \times$ $10^{-5}$ ) and ACPA-negative (OR 1.27, $\mathrm{p}=7.3 \times 10^{-5}$ ) RA subgroups compared to the seropositive counterparts. rs10488631 was exclusively associated within the seronegative RA subgroups (RF-negative: OR 1.24, p = 0.016; ACPA-negative: OR 1.27, $\mathrm{p}=4.1 \times 10^{-3}$ ).

Conclusion. Both the CGGGG indel and rs10488631 are relevant for RA susceptibility, especially for seronegative RA. (First Release Aug 1 2011; J Rheumatol 2011;38:2130-2; doi:10.3899/ jrheum.110322)
\end{abstract}

\section{Key Indexing Terms: \\ RHEUMATOID ARTHRITIS \\ GENETIC ASSOCIATION STUDY}

\section{INTERFERON REGULATORY FACTOR 5 SERONEGATIVE}

Rheumatoid arthritis (RA) is a common chronic inflammatory debilitating disease of the joints. Two serological factors, rheumatoid factor (RF) and anticitrullinated peptide antibodies (ACPA), are considered standard markers for RA diagnosis $^{1}$. Studies have shown that seropositive and seronegative RA are 2 independent subgroups with pronounced differences in disease progression, severity, and treatment response, as well as molecular pathophysiology ${ }^{2}$.

The interferon regulatory factor 5 gene (IRF5) is one of the few genetic factors that is primarily associated with seronegative $\mathrm{RA}^{3}$. IRF5 encodes a key transcription factor in the type I interferon (IFN) pathway. Studies have indicated that the IRF5 gene harbors 2 independent haplotypes associated with

From the Department of Medical Sciences, Uppsala University, Uppsala Department of Rheumatology, Umeå University, Umeå; and Department of Medicine, Karolinska Institutet, Stockholm, Sweden.

Supported by research grants from the Swedish Research Council for Medicine and Health, grant no. A028001 and 90318501.

C. Wang, MS; J.K. Sandling, PhD; A-C. Syvänen, PhD, Department of Medical Sciences, Uppsala University; H. Kokkonen, MS; M. Johansson, PhD; S. Rantapää-Dahlqvist, MD, PhD, Department of Rheumatology, Umeå University; M. Seddighzadeh, PhD; L. Padyukov, MD, PhD, Department of Medicine, Karolinska Institutet.

Address correspondence to Dr. A-C. Syvänen, Department of Medical Sciences, Uppsala University, Molecular Medicine, Research Department II, Entrance 70, 3rd Floor, Academic Hospital, SE-75185 Uppsala, Sweden.E-mail: ann-christine.syvanen@medsci.uu.se

Full Release Article. For details see Reprints/Permissions at jrheum.org Accepted for publication May 26, 2011. autoimmune disorders ${ }^{4}$, the first tagged by a 5 -bp insertion-deletion polymorphism (CGGGG indel) with either 3 or 4 copies of the repeat unit, located in the 5 ' region of the IRF5 gene. The second independent signal is from the 3' region of the IRF5 gene, tagged by the single-nucleotide polymorphism (SNP) rs10488631. Interestingly, for systemic lupus erythematosus (SLE) and primary Sjögren's syndrome, the 5' and 3' variants show comparable association signals; whereas for inflammatory bowel diseases and multiple sclerosis it is the 5 , variants that dominate the disease risk ${ }^{5}$.

We investigated the CGGGG indel and the rs10488631 SNP for association with RA or RA serological subgroups.

\section{MATERIALS AND METHODS}

Subjects. RA patients from the Epidemiological Investigation of Rheumatoid Arthritis (EIRA) study were residents in the southern and central part of Sweden, and control subjects were selected from the Swedish population registry. The Northern Sweden Rheumatoid Arthritis (NSRA) study included RA patients from the 4 northernmost counties of Sweden, and controls were recruited from the Medical Biobank of Northern Sweden. Serological status for RF and ACPA was determined as described ${ }^{6,7}$. Written or verbal consent was obtained from all subjects. The ethics committees of the Karolinska Institutet or Umeå University Hospital approved the respective studies. Table 1 provides additional information on the study subjects.

Genotyping. The CGGGG indel and the rs 10488631 SNP were genotyped as described ${ }^{4,5}$. The call rates for the CGGGG indel and rs 10488631 were over $90 \%$. No discrepant genotypes were observed upon repeated genotyping of $\sim 10 \%$ of the samples for both markers, nor was there any deviation from Hardy-Weinberg equilibrium.

Statistical analysis. PLINK software (Center for Human Genetic Research, Massachusetts General Hospital, Boston, MA, USA; http://pngu.mgh.har-

Personal non-commercial use only. The Journal of Rheumatology Copyright (C) 2011. All rights reserved. 
Table 1. Clinical characteristics of patients with RA and controls from the Epidemiological Investigation of Rheumatoid Arthritis (EIRA) and Northern Sweden Rheumatoid Arthritis (NSRA) studies.

\begin{tabular}{lll}
\hline Characteristic & EIRA & NSRA \\
\hline Participants, n (case:control) & $2455(1530: 925)$ & $1681(770: 911)$ \\
Age, yrs (case:control)* & $51.4 \pm 12.3(50.9 \pm 12.5: 52.1 \pm 11.8)$ & $57.3 \pm 13.1(55.2 \pm 14.1: 59.1 \pm 11.8)$ \\
Female, \% (case:control) & $71.4(70.6: 72.8)$ & $70.6(67.8: 73.0)$ \\
RF-negative cases, $\%$ & 33.8 & 25.3 \\
ACPA-negative cases, \% & 38.9 & 31.4 \\
\hline
\end{tabular}

* Age represented as mean \pm SD. RA: rheumatoid arthritis; RF: rheumatoid factor; ACPA: anti-citrullinated peptide antibodies.

vard.edu/ purcell/plink/) was applied for Hardy-Weinberg equilibrium tests and association analysis.

\section{RESULTS}

When the whole set of patients was analyzed, the CGGGG indel was significantly associated with RA in the EIRA study and marginally associated with RA in the NSRA study (Table 2). As for other autoimmune diseases, the $4 \times$ allele was the risk allele. Stratified analysis supported the preferential associations of the CGGGG indel in the seronegative RA subgroups (RF-negative ${ }_{\text {comb }}$ : OR $1.29, \mathrm{p}=7.9 \times 10^{-5}$; ACPA-negative $_{\text {comb: }}$ : OR 1.27, $\mathrm{p}=7.3 \times 10^{-5}$ ) compared to the seropositive counterparts. For the $\mathrm{C}$ allele of the rs 10488631 SNP, the only consistent association signals in both the EIRA and NSRA studies, confirmed by a combined analysis, were from the ACPA-negative RA subgroups (ACPA-negative ${ }_{\mathrm{comb}}$ : OR $\left.1.27, \mathrm{p}=4.1 \times 10^{-3}\right)$.

\section{DISCUSSION}

Although we have previously reported several 5' variants of the IRF5 gene in RA susceptibility ${ }^{3}$, the most promising functional candidate in this region is the CGGGG indel reported here. Its $4 \times$ allele carries an additional CGGGG repeat unit compared to the nonrisk allele; this allows more binding of the transcription factor SP1, which has been shown to cause elevated IRF5 expression ${ }^{4}$. However, the risk for ACPA-negative RA conferred by the CGGGG indel and the 5' SNP rs3807306 (which was reported previously as the most strongly associated SNP) is highly similar $\left(\mathrm{OR}_{\mathrm{CGGGG}}\right.$ indel $=1.27 ; \mathrm{OR}_{\mathrm{rs} 3807306}$ $=1.28)^{3}$. Another variant of functional potential in this region

Table 2. Allelic association analysis of IRF5 gene variants and RA.

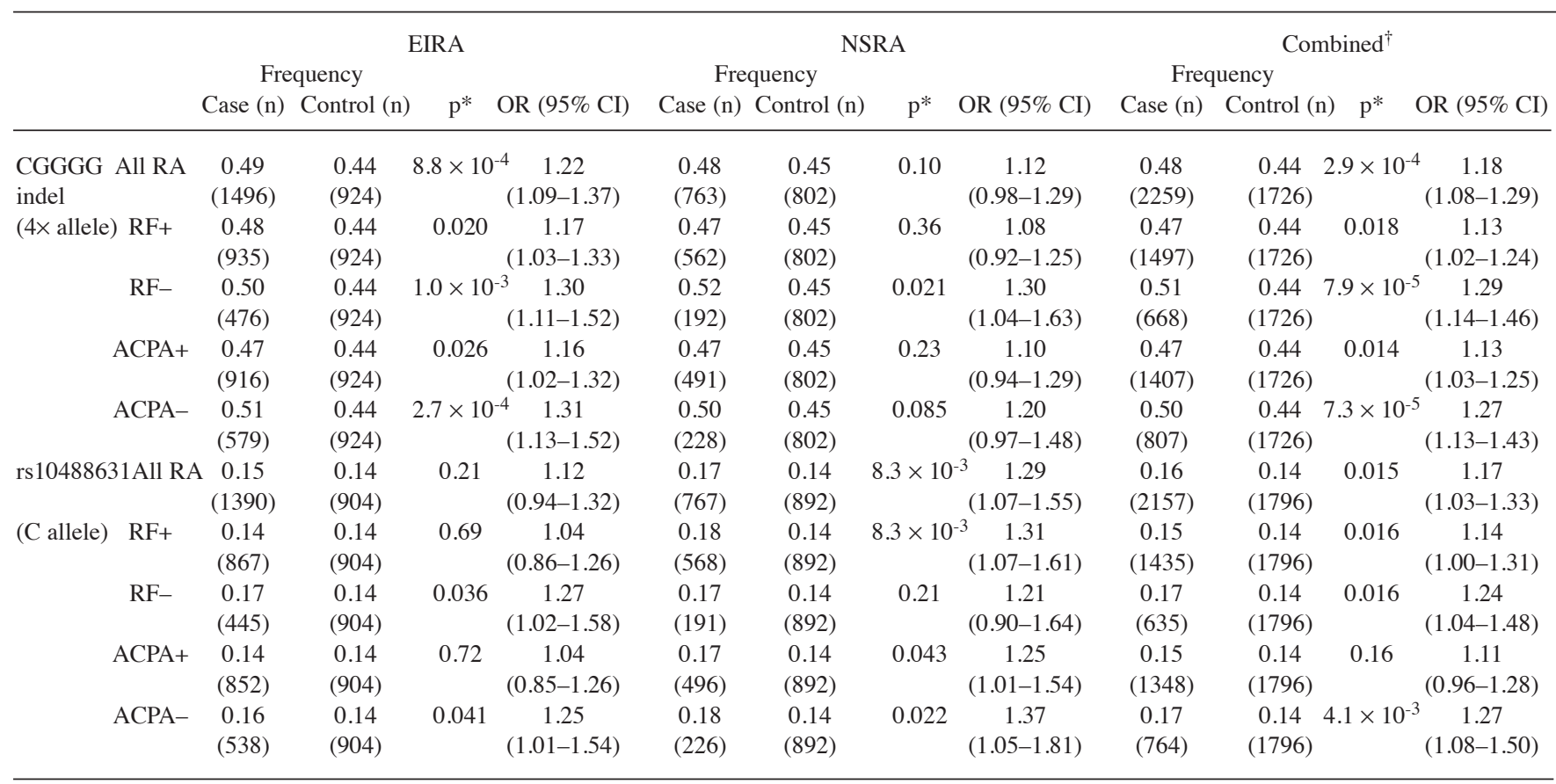

EIRA: Epidemiological Investigation of Rheumatoid Arthritis; NSRA: Northern Sweden Rheumatoid Arthritis study; RF: rheumatoid factor; ACPA: anticitrullinated peptide antibodies. * 2 -sided chi-square tests; $<0.05$ considered statistically significant. ${ }^{\dagger}$ Combined analysis of the EIRA and NSRA studies was achieved by pooling genotype data. This strategy was supported by chi-square-based homogeneity tests, which did not show any significant differences in allele distributions for CGGGG indel or rs 10488631 between studies.

Personal non-commercial use only. The Journal of Rheumatology Copyright $\subset$ 2011. All rights reserved. 
is the rs10954213 SNP, which may create a functional polyadenylation site and influence the stability of IRF5 messenger RNA. In addition, the rs2004640 SNP has been reported to create an alternative splice site in $I R F 5^{8}$, and the existence of additional functional variants cannot be excluded. As for the 3' variants of the IRF5 gene, no biological hypothesis for their functions has been proposed. However, the $\mathrm{C}$ allele of the rs10488631 SNP has been reported to associate with enhanced IRF5 expression independently of the CGGGG indel ${ }^{9}$. Our study demonstrated that the association pattern of the IRF5 gene variants in RA, and more notably with seronegative RA, resembles the patterns observed for SLE and primary Sjögren's syndrome, in which both the 5' and 3' variants are associated with and confer comparable risk to the disease $^{4,5}$.

The preferential association of the IRF5 gene variants with seronegative RA has also been reported in other populations. In a Spanish RA case-control study, the 5' SNP rs2004640, rs752637, and rs10954213 and the SNP rs10488631 were found to have stronger associations with ACPA-negative $\mathrm{RA}^{10}$. A study with French and Western European RA family trios reported the risk effects of the 3 SNP rs 3757385 , rs2004640, and rs10954213, where the signals were also stronger in the RF-negative RA subgroup ${ }^{11}$. Meanwhile, contradictory results were observed from a Euro-American and a Korean RA case-control study. The former study reported that the 3' SNP rs10488631 was exclusively associated with ACPA-positive RA ${ }^{12}$; and the latter detected association of the

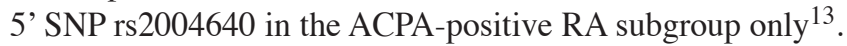
Low power due to the sample sizes, lower prevalence and higher clinical heterogeneity of seronegative RA, varying risk allele frequencies and genetic heterogeneity among populations may account for these inconsistent observations.

Indeed, although seropositive and seronegative RA seem to be comparable in heritability ${ }^{14}$, their distinct genetic etiologies have been addressed in genome-wide association studies and other large-scale studies ${ }^{15}$. Evidence on genetic factors shared by these 2 RA subgroups is also accumulating. These findings emphasize the different, but related, pathogenic mechanisms underlying seropositive and seronegative RA.

\section{ACKNOWLEDGMENT}

We thank Annika Ahlford, Sofia Nordman, Ann-Christin Wiman, and Torbjörn Öst for assistance with genotyping, and the members of the Epidemiological Investigation of Rheumatoid Arthritis group for aiding with data collection.

\section{REFERENCES}

1. Aletaha D, Neogi T, Silman AJ, Funovits J, Felson DT, Bingham CO 3rd, et al. 2010 rheumatoid arthritis classification criteria: an American College of Rheumatology/European League Against Rheumatism collaborative initiative. Ann Rheum Dis 2010;69:1580-8.
2. Klareskog L, Ronnelid J, Lundberg K, Padyukov L, Alfredsson L. Immunity to citrullinated proteins in rheumatoid arthritis. Annu Rev Immunol 2008;26:651-75.

3. Sigurdsson S, Padyukov L, Kurreeman FA, Liljedahl U, Wiman AC, Alfredsson L, et al. Association of a haplotype in the promoter region of the interferon regulatory factor 5 gene with rheumatoid arthritis. Arthritis Rheum 2007;56:2202-10.

4. Sigurdsson S, Goring HH, Kristjansdottir G, Milani L, Nordmark $\mathrm{G}$, Sandling JK, et al. Comprehensive evaluation of the genetic variants of interferon regulatory factor 5 (IRF5) reveals a novel 5 bp length polymorphism as strong risk factor for systemic lupus erythematosus. Hum Mol Genet 2008;17:872-81.

5. Nordmark G, Kristjansdottir G, Theander E, Eriksson P, Brun JG, Wang C, et al. Additive effects of the major risk alleles of IRF5 and STAT4 in primary Sjogren's syndrome. Genes Immun 2009;10:68-76.

6. Padyukov L, Silva C, Stolt P, Alfredsson L, Klareskog L. A gene-environment interaction between smoking and shared epitope genes in HLA-DR provides a high risk of seropositive rheumatoid arthritis. Arthritis Rheum 2004;50:3085-92.

7. Kokkonen H, Johansson M, Innala L, Jidell E, Rantapaa-Dahlqvist $\mathrm{S}$. The PTPN22 1858C/T polymorphism is associated with anti-cyclic citrullinated peptide antibody-positive early rheumatoid arthritis in northern Sweden. Arthritis Res Ther 2007;9:R56.

8. Cunninghame Graham DS, Manku H, Wagner S, Reid J, Timms K, Gutin A, et al. Association of IRF5 in UK SLE families identifies a variant involved in polyadenylation. Hum Mol Genet 2007;16:579-91.

9. Feng D, Stone RC, Eloranta ML, Sangster-Guity N, Nordmark G, Sigurdsson $\mathrm{S}$, et al. Genetic variants and disease-associated factors contribute to enhanced interferon regulatory factor 5 expression in blood cells of patients with systemic lupus erythematosus. Arthritis Rheum 2010;62:562-73.

10. Dieguez-Gonzalez R, Calaza M, Perez-Pampin E, de la Serna AR, Fernandez-Gutierrez B, Castaneda S, et al. Association of interferon regulatory factor 5 haplotypes, similar to that found in systemic lupus erythematosus, in a large subgroup of patients with rheumatoid arthritis. Arthritis Rheum 2008;58:1264-74.

11. Dawidowicz K, Allanore Y, Guedj M, Pierlot C, Bombardieri S, Balsa A, et al. The interferon regulatory factor 5 gene confers susceptibility to rheumatoid arthritis and influences its erosive phenotype. Ann Rheum Dis 2011;70:117-21.

12. Kurreeman F, Liao K, Chibnik L, Hickey B, Stahl E, Gainer V, et al. Genetic basis of autoantibody positive and negative rheumatoid arthritis risk in a multi-ethnic cohort derived from electronic health records. Am J Hum Genet 2011;88:57-69.

13. Kim YJ, Park JH, Kim I, Kim JO, Bae JS, Shin HD, et al. Putative role of functional interferon regulatory factor 5 (IRF5) polymorphism in rheumatoid arthritis in a Korean population. J Rheumatol 2008;35:2106-18.

14. van der Woude D, Houwing-Duistermaat JJ, Toes RE, Huizinga TW, Thomson W, Worthington J, et al. Quantitative heritability of anti-citrullinated protein antibody-positive and anti-citrullinated protein antibody-negative rheumatoid arthritis. Arthritis Rheum 2009;60:916-23.

15. Padyukov L, Seielstad M, Ong RT, Ding B, Ronnelid $\mathrm{J}$, Seddighzadeh $\mathrm{M}$, et al. A genome-wide association study suggests contrasting associations in ACPA-positive versus ACPA-negative rheumatoid arthritis. Ann Rheum Dis 2011;70:259-65. 